Tropical Journal of Pharmaceutical Research June 2016; 15 (6): 1335-1339

ISSN: $1596-5996$ (print); 1596-9827 (electronic) (C) Pharmacotherapy Group, Faculty of Pharmacy, University of Benin, Benin City, 300001 Nigeria. All rights reserved.

\title{
Clinical effect of intravenous thrombolysis combined with nicorandil therapy in patients with acute ST-segment elevation myocardial infarction
}

\author{
Shu-Hua $\mathrm{Yu}^{1}$, Lin $\mathrm{Li}^{2 *}$ and Shen Zhang ${ }^{2}$ \\ ${ }^{1}$ Geriatric Cardiology, ${ }^{2}$ Geriatric Neurology, Zhengzhou Central Hospital Affiliated to Zhengzhou University, Zhengzhou, \\ 450007, PR China
}

*For correspondence: Email: lilinysh@163.com

Received: 13 January 2015

Revised accepted: 20 May 2016

\begin{abstract}
Purpose: To evaluate the effectiveness of intravenous thrombolysis in combination with nicorandil in the treatment of acute ST-segment elevation myocardial infarction (STEMI).

Methods: Patients who developed acute STEMI and underwent intravenous thrombolysis in the hospital were selected and divided into observation group $(n=128)$ and control group $(n=114)$. Besides thrombolytic therapy, the observation group was also given $20 \mathrm{mg}$ of nicorandil. The control group received conventional thrombolytic therapy only. Clinical effects and rehabilitation of patients were observed.

Results: Cardiac troponin I (cTNI) level of the observation group was $4.0 \pm 1.5,8.3 \pm 2.8$ and $9.8 \pm 3.9$ after 4,12 and $24 \mathrm{~h}$, respectively, which is much lower than $5.8 \pm 1.4,11.4 \pm 2.7$ and $13.2 \pm 4.2$ in the control group $(p<0.05)$. ST-segment resolution of observation group was higher $(44 \pm 14,52 \pm 17,69 \pm$ 21 and $80 \pm 18) \%$ at different time points, compared with the control group $(p<0.05)$. The proportion of patients with Curtis-Walker score $>3$ points, and ventricular wall motion score $(4.70 \% ; 1.38 \pm 0.11)$ in the observation group were both lower than those of the control group $(21.00 \% ; 1.43 \pm 0.15)(p<0.05)$. The difference in adverse cardiac events between the observation group $(N=6,4.70 \%)$ and control group ( $N=12,10.50 \%)$ was not statistically significant $(p>0.05)$

Conclusion: Combining intravenous thrombolysis with nicorandil therapy can enhance myocardial perfusion level, reduce myocardial damage, improve cardiac function and decrease risk of arrhythmia for acute STEMI patients.
\end{abstract}

Keywords: ST-segment elevation, Myocardial infarction, Arrhythmia, Nicorandil, ST-segment, Thrombolytic therapy, Curtis-Walker score

Tropical Journal of Pharmaceutical Research is indexed by Science Citation Index (SciSearch), Scopus, International Pharmaceutical Abstract, Chemical Abstracts, Embase, Index Copernicus, EBSCO, African Index Medicus, JournalSeek, Journal Citation Reports/Science Edition, Directory of Open Access Journals (DOAJ), African Journal Online, Bioline International, Open-J-Gate and Pharmacy Abstracts

\section{INTRODUCTION}

ST segment elevation myocardial infarction (STEMI), a kind of acute myocardial infarction (MI), is high in incidence and mortality. Like patients with general acute $\mathrm{Ml}$, patients who develop STEMI also have symptoms of chest pain and arrhythmia; but the most representative characteristic is a significant elevation of ST- segment on the electrocardiogram [1]. The incidence of STEMI has become increasingly high of recent, seriously threatening people's health. It is a key point to timely, continuously and thoroughly dredge infarction related blood vessels in the treatment of STEMI [2]. Percutaneous coronary intervention $(\mathrm{PCl})$ is considered as the optimal scheme for recovering blood flow of coronary artery as it is effective in 
opening infarction related coronary artery, recovering blood transport and rescuing endangered myocardial cells [3]. However, most patients with STEMI fail to receive $\mathrm{PCl}$ within effective time window due to the imbalanced distribution of medical resources in China.

It has been found that, thrombolytic therapy is still the preferred method for treating STEMI and $60 \%$ patients tend to accept thrombolytic therapy, though $\mathrm{PCl}$ is extensively promoted in clinic in recently years [4]. Thrombolytic therapy is rapid, convenient, economic and easy to operate. Thrombolytic therapy can dredge blood vessels by resolving thrombus existing in coronary artery, thereby recovering blood perfusion of tissue and organs partially or completely. But it is only effective in opening infarction related blood vessels but not beneficial for early recovery of cardiac function. Experts in China and those from some foreign countries have proved that nicorandil is effective in protecting ischemic myocardium and narrowing infarct size $[5,6]$. The study selected some patients for a clinical comparative experiment, aiming to discuss the effectiveness of intravenous thrombolysis in combination with nicorandil in improving reperfusion of patients with STEMI.

\section{EXPERIMENTAL}

In this study, 242 patients who suffered from STEMI and received thrombolytic therapy in Zhengzhou Central Hospital Affiliated to Zhengzhou University, China, between March 2011 and March 2014, were selected. They were classified into observation group and control group. The observation group was given $20 \mathrm{mg}$ of nicorandil (thrice daily) immediately after definite diagnosis, besides nicorandil; the control group only received thrombolytic therapy. Patients who showed $0.1 \mathrm{mV}$ over increase (limb leads) or $0.2 \mathrm{mV}$ over increase (precordial leads) in ST-segment in electrocardiogram, had newly emerged left bundle branch block, or had the disease less than $12 \mathrm{~h}$ before diagnosis, and had no contraindications to thrombolysis were included, while patients who were aged over 75 years, had cardiogenic shock, were able to fulfill $\mathrm{PCl}$ within 90 min after being admitted into the hospital and rejected to join the study were excluded. This study was approved by the medical ethics committee of Zhengzhou Central Hospital Affiliated to Zhengzhou University (approval no. YSH20150917) and the studies followed guidelines of Declaration of Helsinki [7], and all patients each gave a signed informed consent. Detailed procedures for thrombolytic therapy were as follows. Patients were given 300 $\mathrm{mg}$ of aspirin and $300 \mathrm{mg}$ of clopidogrel immediately after being confirmed to have acute STEMI. For thrombolysis, $(1.0-1.5) \times 10^{6}$ units of urokinase were added to $100 \mathrm{ml}$ of normal saline and then the mixture was intravenously injected in $30 \mathrm{~min}$. For patients receiving reteplase thrombolysis, they were intravenously injected with $10 \mathrm{mU}$ of reteplase and then another $10 \mathrm{mU}$ of reteplase if reperfusion did not occur.

\section{Indications for infarction related blood vessel reperfusion}

Thrombolysis was considered to be successfully performed when two of the following events occurred: ST segment resolution was over $50 \%$ or chest pain significantly relieved in $2 \mathrm{~h}$ after thrombolysis or patients were found with reperfusion-induced arrhythmia. Patients whose treatment failed were given rescue $\mathrm{PCl}$ as soon as possible.

\section{Measurement observation index}

Myocardial damage degree, ST segment resolution, incidence of acute arrhythmia and cardiac function were observed when patients were hospitalized. Moreover, cardiac function and incidence of adverse cardiac events were followed up for 6 months.

\section{Statistical analysis}

SPSS19.0 software package was used for analyzing the data obtained. The data are expressed as mean \pm standard deviation (SD). Data conforming to normal distribution was processed by Student's t-test. Data at different time points were analyzed using analysis of variance test. Other data were expressed as percentage and processed by Chi-square test. Fisher exact probability method was used if theoretical frequency was $<5$. Differences were considered statistically significant if $p<0.05$.

\section{RESULTS}

\section{Baseline data for the two groups}

In total, 300 patients suffering from STEMI received thrombolytic therapy. Of these, 52 cases failed and 6 cases were found with gastrointestinal bleeding. Eventually, 128 cases were included into the observation group and the remaining 114 cases were recruited into the control group. We observed no statistically significant difference in baseline data between two groups. Baseline data of patients in two groups are shown in Table 1. 


\section{Comparison of cTNI level between two groups}

cTNI level was observed with no significant difference between two groups before treatment. However after thrombolytic therapy was performed, there was a difference between the groups at different time points. The difference between the two groups, difference at different time points and difference of interaction between groups and time points were statistically significant $(p<0.01)$; cTNI level of the observation group was much lower than the control group as shown in Table 2.

\section{Comparison of ST segment resolution between two groups}

Results of ST segment resolution observed after thrombolytic therapy showed that, the difference between the two groups, difference at different time points and difference of interaction between groups and time points were statistically significant $(p<0.05$ or $p<0.01)$; ST resolution in the observation group was more obvious than that of the control group (Table 3).

\section{Comparison of incidence of arrhythmia between two groups}

Incidence of burst ventricular tachycardia and ventricular fibrillation in two groups was found with no significant difference; but incidence of refractory ventricular extrasystole, bradycardia arrhythmia and proportion of cases with 3 points over Curtis-Walker score in the observation group were all remarkably lower than those of the control group $(p=0.010, p=0.020, p=$ 0.014 ) as shown in Table 4.

Table 1: Comparison of baseline data between two groups

\begin{tabular}{|c|c|c|c|c|}
\hline Group & $\begin{array}{l}\text { Control group } \\
\qquad(\mathrm{N}=114)\end{array}$ & $\begin{array}{c}\text { Observation } \\
\text { group } \\
(\mathrm{N}=128)\end{array}$ & Statistics & $P$-value \\
\hline Gender $\{n(\%)\}$ & $\begin{array}{l}72(63.20) \\
42(36.80)\end{array}$ & $\begin{array}{l}90(70.30) \\
38(29.70)\end{array}$ & $X^{2}=0.412$ & $>0.05$ \\
\hline $\begin{array}{l}\text { Age (years, } \pm S D) \\
\text { Body mass index }\left(\mathrm{kg} / \mathrm{m}^{2}\right)\end{array}$ & $\begin{array}{l}60.30 \pm 11.10 \\
25.20 \pm 3.80\end{array}$ & $\begin{array}{c}58.40 \pm 11.80 \\
24.10 \pm 3.60\end{array}$ & $\begin{array}{l}t=0.909 \\
t=1.634\end{array}$ & $\begin{array}{l}>0.05 \\
>0.05\end{array}$ \\
\hline $\begin{array}{lc}\text { Infarction location } & \text { Antetheca } \\
\{\boldsymbol{n}(\%)\} & \text { Non-antetheca }\end{array}$ & $62(45.60)$ & $70(54.70)$ & $X^{2}=0.663$ & $>0.05$ \\
\hline Heart rate (time/min) & $74.70 \pm 7.80$ & $76.20 \pm 6.90$ & $t=1.123$ & $>0.05$ \\
\hline Serum creatinine ( $\mu \mathrm{mol} / \mathrm{L})$ & $80.20 \pm 12.10$ & $79.10 \pm 14.70$ & $t=0.446$ & $>0.05$ \\
\hline $\begin{array}{r}\text { Time from onset to thrombolysis (h) } \\
\text { Systolic pressure }\end{array}$ & $\begin{array}{l}3.80 \pm 1.50 \\
130 \pm 14.60\end{array}$ & $\begin{array}{l}3.40 \pm 1.20 \\
126 \pm 15.90\end{array}$ & $\begin{array}{l}t=1.627 \\
t=1.435\end{array}$ & $\begin{array}{l}>0.05 \\
>0.05\end{array}$ \\
\hline (mmHg) & $77 \pm 9.90$ & $74 \pm 10.50$ & $t=1.611$ & $>0.05$ \\
\hline
\end{tabular}

Table 2: Comparison of cTNi level between the two groups (Mean $\pm \mathrm{SD}, \mu \mathrm{g} / \mathrm{L}$ )

\begin{tabular}{|c|c|c|c|c|c|}
\hline \multirow{2}{*}{ Group } & \multirow{2}{*}{$\mathbf{N}$} & \multicolumn{4}{|c|}{ cTNI } \\
\hline & & On admission & $4 \mathrm{~h}$ & 12h & $24 \mathrm{~h}$ \\
\hline Control group & 114 & $0.90 \pm 0.35$ & $5.8 \pm 1.4$ & $11.4 \pm 2.7$ & $13.2 \pm 4.2$ \\
\hline Observation group & 128 & $0.80 \pm 0.31$ & $4.0 \pm 1.5$ & $8.3 \pm 2.8$ & $9.8 \pm 3.9$ \\
\hline Between groups & \multicolumn{3}{|c|}{$F=16.86$} & \multicolumn{2}{|c|}{$p<0.01$} \\
\hline Time point & \multicolumn{3}{|c|}{$F=320.26$} & \multicolumn{2}{|c|}{$p<0.01$} \\
\hline $\begin{array}{l}\text { Between groups \& time } \\
\text { point }\end{array}$ & \multicolumn{3}{|c|}{$F=2.98$} & \multicolumn{2}{|c|}{$p<0.05$} \\
\hline
\end{tabular}

Table 3: segment resolution of the two groups (mean \pm SD, \%)

\begin{tabular}{lccccc}
\hline \multirow{2}{*}{ Group } & \multirow{2}{*}{$\mathbf{N}$} & \multicolumn{3}{c}{$\mathbf{S T}$ segment resolution } \\
\cline { 3 - 5 } & & $\mathbf{2 h}$ & $\mathbf{4 h}$ & $\mathbf{6 h}$ & $\mathbf{1 2 h}$ \\
\hline Control group & 114 & $41 \pm 12$ & $46 \pm 15$ & $58 \pm 18$ & $72 \pm 20$ \\
Observation group & 128 & $44 \pm 14$ & $52 \pm 17$ & $69 \pm 21$ & $80 \pm 18$ \\
Between groups & & $\mathrm{F}=15.38$ & & $p<0.01$ \\
Time point & & $\mathrm{F}=57.59$ & & $p<0.01$ \\
Between groups \& time point & & $\mathrm{F}=2.76$ & & $p<0.05$ \\
\hline
\end{tabular}


Table 4: Comparison of incidence of arrhythmia between two groups [n (\%)]

\begin{tabular}{|c|c|c|c|c|c|}
\hline Group & $\begin{array}{c}\text { Refractory } \\
\text { ventricular } \\
\text { extrasystole }\end{array}$ & $\begin{array}{c}\text { Burst } \\
\text { ventricular } \\
\text { tachycardia }\end{array}$ & $\begin{array}{l}\text { Ventricular } \\
\text { fibrillation }\end{array}$ & $\begin{array}{l}\text { Bradycardia } \\
\text { arrhythmia }\end{array}$ & $\begin{array}{c}\text { Curtis-Walker } \geq \\
3 \text { points }\end{array}$ \\
\hline Group 1* & $56(49.10)$ & $16(14.00)$ & $2(1.80)$ & $48(42.10)$ & $24(21.00)$ \\
\hline Group 2** & 32 (25.00) & $6(4.70)$ & 0 & $28(21.90)$ & $6(4.70)$ \\
\hline$x^{2}$-value & 6.575 & 2.157 & 0.003 & 4.827 & 6.004 \\
\hline P-value & $<0.05$ & $>0.05$ & $>0.05$ & $<0.05$ & $<0.05$ \\
\hline
\end{tabular}

${ }^{*}$ Control $(N=114) ;{ }^{* *}$ Observation group $(N=128)$

\section{DISCUSSION}

In recent years, the incidence of cardiovascular disease in China has to become higher. It has been reported that about 2.5 million people are confirmed to have acute myocardial infarction every year in China [8]. PCl as the optimal treatment method for acute myocardial infarction has not been widely performed due to multiple factors. Statistics demonstrate that, only 29, 231 cases received $\mathrm{PCl}$ in China in 2013 [9]. As a result, most people with acute STEMI cannot be effectively treated by $\mathrm{PCl}$ at the first visit. Since the 1980s, several large-scale, multicentric, randomized and double-blinded, clinical control tests [10-12] have proven that, mortality of people who receive thrombolytic therapy for treating acute STEMI is $25-47 \%$ lower than people who are given placebo, confirming the important position of thrombolytic therapy in the treatment of acute STEMI.

However, thrombolytic therapy is found to be less effective in opening occlusive coronary artery. Even the third generation of thrombolytic drug only has a possibility of $70 \%$ in opening infarction-related blood vessels and a possibility of $60 \%$ in achieving TIMI3-level blood flow, and the drug may affect recovery of cardiac function [13]. Thus severe risk of myocardial ischemia and vascular occlusion cannot be totally avoided even when STEMI patients complete thrombolytic therapy successfully, which may not be beneficial for rescuing more myocardial cells [14].

Nicorandil is the first K (ATP) channel opener possessing effects similar to nitrate and being applied clinically [15]. Nicorandil can open K (ATP) channel of vascular smooth muscle, inhibit opening of voltage dependent $\mathrm{Ca}^{2+}$ channel as well as expand coronary artery and vessels through NO-PKG approach, thus to reduce microcirculation resistance, improve blood supply and finally lower incidence of slow coronary flow induced by $\mathrm{PCl}$. Infarction related myocardial cells die in two ways; that is by necrosis and apoptosis [16]. Calcium overload within cells or mitochondria contributes to the death of myocardial cells [17]. It has been proved that, intravenous injection of nicorandil before angioplasty for patients with acute anterior myocardial infarction is more effective in improving left ventricular function, reducing malignant arrhythmia and lowering incidence of no-reflow phenomenon compared to angioplasty alone [18].

This study showed that, taking nicrorandil before thrombolytic therapy could also reduce myocardial damage induced by ischemia, relieve left ventricular wall motion, lower incidence of arrhythmia and improve cardiac function. Earlier studies $[19,20]$ demonstrate that, amplitude and speed of ST segment resolution after thrombolysis can reflect effect of myocardial perfusion; amplitude of ST segment resolution is in a significant correlation to of left ventricle contraction; rapider ST segment resolution indicates better myocardial perfusion. In this study, ST segment in the observation group declined rapidly and significantly, indicating that nicrorandil could further improve myocardial perfusion level as well as prognosis of STEMI patients.

\section{Limitations of the study}

In the observation group, the incidence of adverse cardiac events did not show significant decline, which may be correlated to the small size of samples. The current study with small sample size cannot be used for evaluating effects of nicrorandil on cardiac events. Though there is a trend, the difference was not statistically significant. Therefore, a further study with a larger sample size is required.

\section{CONCLUSION}

Intravenous thrombolysis in combination with oral administration of nicrorandil can further enhance myocardial reperfusion level, improve heart function and lower incidence of arrhythmia. It is of great significance to improve long-term prognosis and living quality of STEMI patients. Hence, the therapy strategy is worth applying in clinical practice. 


\section{ACKNOWLEDGEMENT}

The authors sincerely thank all who supported this work.

\section{DECLARATIONS}

\section{Conflict of Interest}

No conflict of interest associated with this work.

\section{Contribution of Authors}

The authors declare that this work was done by the authors named in this article and all liabilities pertaining to claims relating to the content of this article will be borne by them.

\section{REFERENCES}

1. Davidson BP, Kaufmann BA, Belcik JT, Xie A, Qi Y, Lindner JR. Detection of antecedent myocardial ischemia with multiselectin molecular imaging. J Am Coll Cardiol 2012; 60(17): 1690-1697.

2. Zhang QC, Wang CW, Zhang XF, Pan GH. Direct coronary thrombus suction combined with stent implantation for acute myocardial infarction complicated with coronary artery thrombus. J of Chin Pract Diagnosis and Therapy 2011; 25(1): 46-51.

3. Zalewski J, Durak M, Lech P, Gajos G, Undas A, Nessler J, Roslawiecka A, Zmudka K. Platelet activation and microvascular injury in patients with ST-segment elevation myocardial infarction. Kardiologia Polska 2012; 70(7): 677-684

4. Desagher S, Martinou JC. Mitochondria as the central control point of apoptosis. Trends Cell Biol 2000; 10(9): 369-377.

5. Hu DY, Li RJ, Guo CJ, Guo JP, Jia SQ, Li TC, Shang LH. The value of continued $S T$ segment monitoring in evaluation of dynamic changes of infarct-related arteries in early phase of acute myocardial infarction. Chin $\mathrm{J}$ of Cardiol 2001; 29(5): 277-279

6. Prasad A, Stone GW, Stuckey TD, Costantini CO, Zimetbaum PJ, McLaughlin M, Mehran R, Garcia E, Tcheng JE, Cox DA, Grines CL, Lansky AJ, Gersh BJ. Impact of diabetes mellitus on myocardial perfusion after primary angioplasty in patients with acute myocardial infarction. Am Coll Cardiol 2005; 45: 508-514.

7. Declaration of Helsinki. The 59th World Medical Association, 2008.

8. Wang W, Zhu ML, Wang YJ, Wu ZS, Gao RL, Kong LZ, Hu ST. Outline of Chinese Cardiovascular Disease Report (2012). Chin Circulation J 2013; 28(6): 408-412.
9. Tsuchida A, Miura T, Tanno M, Sakamoto J, Miko T, Kuno A, Matsumoto $T$, Ohnuma $Y$, Lchikawa $Y$, Shimamoto K. Infarct size limitation by nicorandil: roles of mitochondrial K(ATP) channels, sarcolemmal K (ATP) channels, and protein kinase C. J Am Coll Cardiol 2002; 40(8): 1523-1530.

10. Ganz W. The thrombolysis in myocardial infarction (TIMI) trial. N Engl J Med 1985; 313(16):1018.

11. Gruppo Italiano per lo Studio della Streptochinasi nell' Infarto Miocardico (GISSI). Effectiveness of intravenous thrombolytic treatment in acute myocardial infarction. Lancet 1986; 1(8478): 397-402.

12. Wilcox RG, Olsson CG, Skene AM, Von Der Lippe G, Jensen G, Hampton JR. Trial of tissue plasminogen activator for mortality reduction in acute myocardial infarction. Anglo-Scandinavian Study of Early Thrombolysis (ASSET). Lancet 1988; 2(8610): 525-530.

13. Schroder R. Prognostic impact of early ST-segment resolution in acute ST-elevation myocardial infarction. Circulation 2004; 110(21): e506-510.

14. The GUSTO Angiographic Investigators. The effects of tissue plasminogen activator, streptokinase, or both on coronary-artery patency, ventricular function, and survival after acute myocardial infarction. N Engl J Med 1993; 329(22): 1615-1622.

15. Noman A, Egred M, Bagnall A, Spyridopoulos I, Jamieson S, Ahmed J. Impact of thrombus aspiration during primary percutaneous coronary intervention on mortality in ST-segment elevation myocardial infarction. Eur Heart J 2012; 33(24): 3054-3061.

16. Konstantinidis K, Whelan RS, Kitsis RN. Mechanisms of cell death in heart disease. Arterioscler Thromb Vasc Biol 2012; 32(7): 1552-1562.

17. Lei JY, Huang W. Research Progress of Mitochondrial Membrane Mediated Cell Death Pathways during Acute Myocardial Infarction - Radicals of Calcium and Reactive Oxygen Species. Adv in Cardiovascular Dis 2014; 35(2): 200-204.

18. Ito $H$, Taniyama $Y$, Iwakura $K$, Nishikawa N, Masuyama T, Kuzuya T, Hori M, Higashino Y, Fujii K, Minamino T. Intravenous nicorandil can preserve microvascular integrity and myocardial viability in patients with reperfused anterior wall myocardial infarction. J Am Coll Cardiol 1999; 33(3): 654-660.

19. Ota S, Nishikawa H, Takeuchi M, Nakajima K, Nakamura T, Okamoto S, Setsuda M, Makino K, Yamakado T, Nakano T. Impact of nicorandil to prevent reperfusion injury in patients with acute myocardial infarction: Sigmart Multicenter Angioplasty Revascularization Trial (SMART). Circ J 2006; 70(9): 1099-1104.

20. Ikeda N, Yasu T, Kubo N, Hashimoto S, Tsuruya Y, Fujiii M. Nicorandil versus isosorbide dinitrate as adjunctive treatment to direct balloon angioplasty in acute myocardial infarction. Heart 2004; 90(2): 181-185. 